\title{
1,25-Dihydroxyvitamin D3 increases testosterone-induced 17beta-estradiol secretion and reverses testosterone-reduced connexin 43 in rat granulosa cells
}

Ching-Tien Lee', Jiz-Yuh Wang ${ }^{2}$, Kuang-Yi Chou ${ }^{3}$ and Ming-I Hsu ${ }^{4 *}$

\begin{abstract}
Background: Aromatase converts testosterone into 17beta-estradiol in granulosa cells, and the converted 17beta-estradiol contributes to follicular maturation. Additionally, excessive testosterone inhibits aromatase activity, which can lead to concerns regarding polycystic ovary syndrome (PCOS). Generally, 1,25-dihydroxyvitamin D3 $(1,25 \mathrm{D} 3)$ supplements help to improve the symptoms of PCOS patients who exhibit low blood levels of 1,25D3. Therefore, this study investigated the interaction effects of 1,25D3 and testosterone on estrogenesis and intercellular connections in rat granulosa cells.
\end{abstract}

Methods: Primary cultures of granulosa cells were treated with testosterone or testosterone plus 1,25D3, or pre-treated with a calcium channel blocker or calcium chelator. Cell lysates were subjected to western blot analysis to determine protein and phosphorylation levels, and 17beta-estradiol secretion was examined using a radioimmunoassay technique. Cell viability was evaluated by MTT reduction assay. Connexin 43 (Cx43) mRNA and protein expression levels were assessed by qRT-PCR, western blot, and immunocytochemistry.

Results: Testosterone treatment ( 0.1 and $1 \mathrm{microg} / \mathrm{mL}$ ) increased aromatase expression and 17beta-estradiol secretion, and the addition of 1,25D3 attenuated testosterone (1 microg $/ \mathrm{mL})$-induced aromatase expression but improved testosterone-induced $17 \mathrm{beta}$-estradiol secretion. Furthermore, testosterone-induced aromatase phosphotyrosine levels increased at $10 \mathrm{~min}, 30 \mathrm{~min}$ and $1 \mathrm{~h}$, whereas 1,25D3 increased the longevity of the testosterone effect to $6 \mathrm{~h}$ and $24 \mathrm{~h}$. Within 18-24 h of treatment, 1,25D3 markedly enhanced testosterone-induced 17beta-estradiol secretion. Additionally, pre-treatment with a calcium channel blocker nifedipine or an intracellular calcium chelator BAPTA-AM reduced 1,25D3 and testosterone-induced 17beta-estradiol secretion. Groups that underwent testosterone treatment exhibited significantly increased estradiol receptor beta expression levels, which were not affected by 1,25D3. Neither testosterone nor 1,25D3 altered 1,25D3 receptor expression. Finally, at high doses of testosterone, Cx43 protein expression was decreased in granulosa cells, and this effect was reversed by co-treatment with 1,25D3.

Conclusions: These data suggest that 1,25D3 potentially increases testosterone-induced 17beta-estradiol secretion by regulating aromatase phosphotyrosine levels, and calcium increase is involved in both 1,25D3 and testosterone-induced 17beta-estradiol secretion. 1,25D3 reverses the inhibitory effect of testosterone on Cx43 expression in granulosa cells.

Keywords: 17beta-estradiol, Estrogenesis, Connexin 43, Testosterone, 1,25-dihydroxyvitamin D3, Polycystic ovary syndrome, Calcium, Granulosa cells

\footnotetext{
* Correspondence: hsumingi@yahoo.com.tw

${ }^{4}$ Department of Obstetrics and Gynecology, Wan Fang Hospital, Taipei

Medical University, Taipei, Taiwan

Full list of author information is available at the end of the article
}

\section{Biomed Central}

(c) 2014 Lee et al.; licensee BioMed Central Ltd. This is an Open Access article distributed under the terms of the Creative Commons Attribution License (http://creativecommons.org/licenses/by/4.0), which permits unrestricted use, distribution, and reproduction in any medium, provided the original work is properly credited. The Creative Commons Public Domain Dedication waiver (http://creativecommons.org/publicdomain/zero/1.0/) applies to the data made available in this article, unless otherwise stated. 


\section{Background}

Biosynthesis of $17 \beta$-estradiol from androgen precursors is catalysed by the enzyme aromatase, which is expressed from the cyp19 gene and exists in the ovaries, placenta, testes, breasts, brain, fat, liver and muscles [1]. 17 $\beta$ Estradiol production and follicular development are controlled by the expression level and activity of aromatase [2]. During follicular growth, aromatase mRNA expression levels in granulosa cells from dominant follicles and $17 \beta$-estradiol levels in the follicular fluid are significantly increased $[3,4]$.

Various studies have demonstrated the role of androgens in stimulating follicular development. Androgen receptors (AR) are observed in primary follicles and advanced-stage follicles, and are detected in the granulosa cells of primordial follicles [5]. Androgens have been shown to stimulate the growth of small antral follicles and inhibit apoptosis of preovulatory follicles in primate ovaries [6,7], whereas AR-knockout mice exhibit greatly increased apoptosis of granulosa cells in preovulatory follicles [8]. Testosterone and dihydrotestosterone (DHT) stimulate the growth of cultured follicles, increase the number of follicles and increase granulosa cell proliferation in mammalian cells [6,7]. Testosterone and androstenedione significantly increase the abundance of aromatase mRNA and the accumulation of $17 \beta$-estradiol $[2,9,10]$. However, excessive testosterone is involved in polycystic ovary syndrome (PCOS), which is the most common endocrine disorder in females and is associated with arrested follicular development and the failure to select a dominant follicle [11]. Deficiency of 1,25-dihydroxyvitamin $\mathrm{D}_{3}\left(1,25 \mathrm{D}_{3}\right)$, an active form of vitamin $\mathrm{D}$, is a common risk factor in patients with PCOS $[12,13]$. A daily $1,25 \mathrm{D}_{3}$ supplement enhances the intestinal absorption of calcium and alleviates both PCOS symptoms and gonadal dysfunction in $1,25 \mathrm{D}_{3}$ receptor (VDR)-null mutant mice [14].

$1,25 \mathrm{D}_{3}$ plays important roles in calcium homeostasis, bone metabolism, and cell differentiation, proliferation, and apoptosis. Immunohistochemistry assays have demonstrated that VDR localizes to the follicles and predominantly exists in the nuclei of granulosa cells, suggesting that it has some role in reproduction [15]. Recent studies have demonstrated that aromatase activity and expression level are low in the ovaries of VDR-null mutant mice, but the activity is increased to $60 \%$ of wild-type levels by calcium supplementation in the normal range. Circulating $17 \beta$-estradiol levels are also low in VDR-null mutant mice and do not rise after calcium supplementation [16]. Taken together, these results indicate that $1,25 \mathrm{D}_{3}$ plays a role in estrogenesis that is only partially mediated by extracellular calcium homeostasis.

It has recently been shown that signalling via $1,25 \mathrm{D}_{3} /$ VDR-mediated protein tyrosine phosphorylation occurs in bone, intestine, muscle and cancer cells [17]. The fast nongenomic responses of $1,25 \mathrm{D}_{3} / \mathrm{VDR}$ in muscle cells involve the phosphotyrosine form of a downstream protein, c-Src $[18,19]$. Interestingly, c-Src is also downstream of the estradiol/membrane-associated estradiol receptor (ER) in the stimulation of aromatase activity. The phosphorylation of aromatase at tyrosine 361 is crucial in the upregulation of aromatase activity through the estradiol/ membrane-associated ER and c-Src signalling in mammalian cell lines [20]. The AR is also localized in the plasma membrane and is associated with Src after testosterone treatment in Sertoli cells [21].

A gap junction is a type of intercellular connection that enables the transfer of various small molecules and ions between cells. Such transfers between granulosa cells and oocytes have been implicated in playing important roles in follicular development and oocyte growth [22]. Gap junctions between granulosa cells contain abundant levels of connexin (Cx) 43, which is present at every stage of follicular growth [23]. The level of $\mathrm{Cx} 43$ protein expression increases during follicular development and decreases with follicular atresia [24]. Oocytes from Cx43-null mice failed to reach meiotic maturation, resulting in infertility [24]. Wu et al. demonstrated that excess DHT reduces Cx43 expression and impairs communication between granulosa cells [25]. Additionally, $1,25 \mathrm{D}_{3}$ increases Cx43 protein levels and Cx43 mRNA stability via the nuclear VDR in human skin fibroblasts [26].

However, no studies have investigated the effect of the testosterone and $1,25 \mathrm{D}_{3}$ interaction on aromatase expression and phosphorylation in granulosa cells. Additionally, the effects of $1,25 \mathrm{D}_{3}$ and testosterone-regulated $17 \beta$-estradiol production and intercellular communication in granulosa cells have not been fully elucidated. We therefore investigated the interactions of $1,25 \mathrm{D}_{3}$ and testosterone to clarify their effects on aromatase protein expression and tyrosine phosphorylation, 17 $\beta$-estradiol secretion and Cx43 protein expression in cultured ovarian granulosa cells.

\section{Methods}

\section{Animal preparation}

Immature female Sprague-Dawley rats were housed in plastic cages and maintained on a $12 \mathrm{~h}$ light $/ 12 \mathrm{~h}$ dark cycle (light on at 6:00 a.m.) with food and water available continuously. The experimental procedures were consistent with the Guidelines of Animal Use and Care from the National Institute of Health and were approved by the Institutional Animal Care and Use Committee of Taipei Medical University-Wang Fang Hospital, Taiwan. Immature female rats at 23-24 days of age were injected with 15 IU PMSG (Sigma, St. Louis, MO, USA) for $48 \mathrm{~h}$ to stimulate the development of preantral follicles to antral 
follicles, and the ovaries of the animals were removed after the animals were sacrificed.

\section{Granulosa cell culture}

The ovaries were cleared from the surrounding fat and oviduct, and punctured with 27-gauge needles in phenol red-free Dulbecco's Modified Eagle's medium (DMEM)/ F12 medium (Invitrogen, Carlsbad, CA, USA), modified as described previously [27]. Granulosa cells were pelleted by centrifugation at $1000 \mathrm{rpm}\left(4^{\circ} \mathrm{C}, 10 \mathrm{~min}\right)$ and resuspended in phenol red-free DMEM/F12 medium with $0.1 \%$ fatty acid-free bovine serum albumin, $1 \%$ fetal bovine serum, and $2 \mu \mathrm{g} / \mathrm{mL}$ bovine insulin. The follicular debris was then removed, and the granulosa cell suspensions were filtered through a cell strainer (BD Falcon, Bedford, MA, USA). The cells were plated at a concentration of $2.5 \times 10^{6}$ per well in a 6-well plate and were allowed to attach and grow to confluence for 1 day at $37^{\circ} \mathrm{C}, 5 \% \mathrm{CO}_{2}$, and $95 \%$ air. The cultured cells were then incubated in serum/phenol red-free medium (DMEM/ F12 containing $0.1 \%$ lactalbumin enzymatic hydrolysate) overnight before the beginning of treatment. The cells were treated with different doses of testosterone $(0.01$, 0.1 or $1 \mu \mathrm{g} / \mathrm{mL}$ ) or testosterone combined with $1,25 \mathrm{D}_{3}$ $(0.1 \mu \mathrm{M})$ in $2 \mathrm{~mL}$ of serum/phenol red-free medium for $24 \mathrm{~h}$. Granulosa cells were pretreated with an L-type calcium channel blocker nifedipine (NIF, $10 \mu \mathrm{M}$, Sigma, St. Louis, MO, USA) or an intracellular calcium chelator bis-(a-aminophe-noxy)-ethane-N,N,N',N'-tetraacetic acid, tetra(acetoxymethyl)-ester (BAPTA-AM, $10 \mu \mathrm{M}$, Tocris, Minneapolis, MN, USA) for $30 \mathrm{~min}$, pretreated with $1,25 \mathrm{D}_{3}$ for $15 \mathrm{~min}$, and treated with one of three testosterone doses or vehicle for $24 \mathrm{~h}$. At the end of the incubation period, the medium was collected, and the cells were lysed in ice-cold lysis buffer containing $50 \mathrm{mM}$ Tris- $\mathrm{HCl}(\mathrm{pH} 8.0), 150 \mathrm{mM} \mathrm{NaCl}, 0.1 \%$ SDS, $0.5 \%$ sodium deoxycholate, $0.1 \%$ Triton $\mathrm{X}-100$, protease inhibitors and phosphatase inhibitors. A protein extract from the supernatant was used for western blot analysis.

\section{Western blot}

The protein content of the extracts was determined using the Bio-Rad Protein Assay Reagent. Equal amounts of the protein extract $(15 \mu \mathrm{g})$ were mixed with loading buffer and subjected to $10 \%$ sodium dodecyl sulfate-polyacrylamide gel electrophoresis, followed by transfer to a PVDF (polyvinylidene difluoride) membrane (Millipore, Billerica, MA, USA). After blocking for $1 \mathrm{~h}$ with $5 \%$ non-fat milk powder in Tris Buffered Saline ( $25 \mathrm{mM}$ Tris, $135 \mathrm{mM} \mathrm{NaCl}$ and $2.5 \mathrm{mM} \mathrm{KCl}$ ) with $0.05 \%$ Tween-20 (TBST), the membranes were incubated overnight with primary antibodies in TBST containing $5 \%$ non-fat milk powder and subsequently with horseradish peroxidase (HRP)-conjugated secondary antibody (Millipore, Billerica, MA, USA) in TBST with 5\% non-fat milk powder at room temperature for $1 \mathrm{~h}$. For experiments involving re-immunoblotting to different antibodies, the blots were stripped in $0.2 \mathrm{M}$ glycine ( $\mathrm{pH} 2.5$ ) and $0.05 \%$ Tween -20 at $80^{\circ} \mathrm{C}$ for $20 \mathrm{~min}$ and then rinsed twice with $0.09 \mathrm{M}$ boric acid (pH 7.4), $0.9 \% \mathrm{NaCl}$, and 0.05\% Tween-20. The membranes were immunoblotted with different antibodies: aromatase (1:1000, Serotec, kidlington, Oxford, UK), phosphotyrosine (1:5000, Millipore, Billerica, MA, USA), Cx43 (1:1000, Novex, San Diego, CA, USA), estradiol receptor $\beta$ (ER $\beta)$ (1:1000, GeneTex, San Antonio, Texas, USA), VDR (1:1000, GeneTex, San Antonio, Texas, USA), and $\beta$-actin (1:10000, Chemicon, Temecula, CA, USA). Immunoreactivity was detected by chemiluminescence autoradiography (ECL kit, Millipore, Billerica, MA, USA) in accordance with the manufacturer's instructions. The protein bands were quantified using the $\mathrm{NIH}$ image J Software.

\section{Immunoprecipitation-western blot analysis}

Granulosa cells were lysed in ice-cold lysis buffer containing $50 \mathrm{mM}$ Tris- $\mathrm{HCl}$ (pH 8.0), $150 \mathrm{mM} \mathrm{NaCl}, 0.1 \%$ SDS, $0.5 \%$ sodium deoxycholate, $0.1 \%$ Triton $\mathrm{X}-100$, protease inhibitors, and phosphatase inhibitors. The clarified lysate was immunoprecipitated at $4{ }^{\circ} \mathrm{C}$ for $4 \mathrm{~h}$ in $300 \mu \mathrm{l}$ of NP40 buffer $(150 \mathrm{mM} \mathrm{NaCl}, 1 \% \mathrm{NP} 40,50 \mathrm{mM}$ Tris- $\mathrm{HCl}$, $\mathrm{pH}$ 8.0, protease inhibitors, and phosphatase inhibitors) with anti-aromatase antibody (Serotec, kidlington, Oxford, UK) and protein G (GE Healthcare, Piscataway, NJ, USA). After washing, the immunoprecipitates were boiled, separated by $10 \%$ SDS-PAGE, and transferred to PVDF membranes. An Easyblot kit (GeneTex, San Antonio, Texas, USA) was used to decrease the interference caused by the heavy and light chains of the IgG. EasyBlocker was used as a blocking buffer to minimize the background caused by protein $\mathrm{G}$ contamination, and an EasyBlot antimouse IgG (HRP) was used that specifically reacts with the native form of mouse IgG and does not bind to the denatured form.

\section{Aromatase activity assay}

The enzyme aromatase is responsible for the synthesis of estradiol from testosterone. Hence, the effect of $1,25 \mathrm{D}_{3}$ on $17 \beta$-estradiol secretion by granulosa cells was used as an indicator of aromatase activity (modified by Zaher Merhi et al., 2014) [28]. To study the effect of $1,25 \mathrm{D}_{3}$ on the aromatase activity, granulosa cells were cultured in 24-well culture plates for $24 \mathrm{~h}$ to attach to the plate. After $24 \mathrm{~h}$ of culture, the cells were treated with testosterone or $1,25 \mathrm{D}_{3} /$ testosterone (i.e. $1,25 \mathrm{D}_{3}$ plus testosterone), the medium was collected at the indicated times (10 min, $30 \mathrm{~min}, 1 \mathrm{~h}, 6 \mathrm{~h}$ and $24 \mathrm{~h}$ ), and the $17 \beta$ estradiol level was measured. In order to exclude the earlier difference in $17 \beta$-estradiol secretion, the culture medium was removed after $18 \mathrm{~h}$ and replaced with fresh 
medium supplemented with testosterone or $1,25 \mathrm{D}_{3} /$ testosterone for another $6 \mathrm{~h}(18-24 \mathrm{~h})$ treatment. The medium was collected for the measurement of $17 \beta$ estradiol concentrations at $18-24 \mathrm{~h}$ after the addition of the testosterone or $1,25 \mathrm{D}_{3} /$ testosterone.

\section{Radioimmunoassay}

The cell culture medium was collected and stored at $-80^{\circ} \mathrm{C}$ until the assay was performed. $17 \beta$-Estradiol levels were assayed using a Coat-A-Count Estradiol RIA kit (Siemens, Dublin, Ireland) according to the manufacturer's protocol. $1 \mathrm{~mL}$ of ${ }^{125}$ I-labeled estradiol and $100 \mu \mathrm{L}$ samples were incubated in anti-estradiol antibody-coated tubes for $3 \mathrm{~h}$ at room temperature. After decanting the mixture and washing the tubes, the radioactivity levels of the tubes were counted in a gamma counter. The counts are inversely related to the amount of $17 \beta$-estradiol present in the sample. The intra assay coefficients of variation for assays ranged between $3 \%$ and $16 \%$, with a mean of $10.2 \%$. The percentage cross-reactivity of this antiserum was $17 \alpha$-estradiol: not detectable; estriol: $0.32 \%$; estrone- $\beta$-D-glucuronide: $1.8 \%$. The limit and highest of detection of the assay was $0-3600 \mathrm{pg} / \mathrm{mL}$.

\section{3-(4,5-dimethylthianol-2-yl)-2,5-diphenyltetrazolium bromide (MTT) reduction assay}

Cell viability was measured by a colorimetric MTT reduction assay performed as first described by Mosoman [29]. Each culture well was incubated in $0.5 \mathrm{mg} / \mathrm{mL}$ MTT (Sigma, St. Louis, MO, USA) culture medium followed by incubation for $4 \mathrm{~h}$ in $5 \% \mathrm{CO}_{2}$ at $37^{\circ} \mathrm{C}$. The culture medium was then aspirated, and cells were lysed with DMSO. Quantitation of MTT reduction was assayed by measuring the absorbance at $570 \mathrm{~nm}$ (against the $630 \mathrm{~nm}$ reference) using an ELISA reader (BioTek, Winooski, VT, USA).

\section{RNA extraction and quantitative reverse transcription polymerase chain reaction (qRT-PCR)}

Total cellular RNA from granulosa cell cultures was isolated using a Total RNA Purification Kit (GeneMark, GMbiolab, Taichung, Taiwan) according to the manufacturer's instructions. RNA concentrations and purity were determined using a NanoDrop ND2000 Spectrophotometer (Thermo Scientific, Wilmington, DE, USA). Firststrand cDNA was synthesized from $300 \mathrm{ng}$ of total RNA using SuperScript III Reverse Transcriptase (Invitrogen, Carlsbad, CA, USA). The cDNA were used as templates in subsequent qPCR by an ABI 7500 PCR Detection System (Applied Biosystem, Foster City, CA, USA). The primer sequences for $\mathrm{Cx} 43$ used for PCR amplifications were as follows: 5'-TTG TTT CTG TCA CCA GTA AC-3' (antisense) and 5'-GAT GAG GAA GGA AGA
GAA GC-3' (sense). GAPDH was used as the internal control: 5'-CCG CCT GCT TCA CCA CCT TCT-3' (antisense) and 5'-GTC ATC ATC TCC GCC CCT TCC3' (sense). Each reaction contained the RT mixture, primers and SYBR Green Master Mix (Invitrogen, Carlsbad, CA, USA) and was carried out with the following profile: initial heating to $95^{\circ} \mathrm{C}$ for $10 \mathrm{~min}$ followed by 40 cycles of heating to $95^{\circ} \mathrm{C}$ for $15 \mathrm{~s}$, incubation at $55^{\circ} \mathrm{C}$ for $30 \mathrm{~s}$ and incubation at $72^{\circ} \mathrm{C}$ for $90 \mathrm{~s}$. Melting-curve analysis and PCR products were run on agarose gels with ethidium bromide staining. Cx43 mRNA levels were normalized to GAPDH and expressed as values relative to the control using the comparative threshold cycle method.

\section{Immunocytochemistry}

Granulosa cells were cultured on poly-L-lysine coated coverslips in 6-well plates. After $24 \mathrm{~h}$ of treatment, the granulosa cells were fixed in cold $4 \%$ paraformaldehyde for $20 \mathrm{~min}$, rinsed three times with phosphate-buffered saline, and permeabilized with $0.1 \%$ Triton. Cells were blocked for $1 \mathrm{~h}$ with $5 \%$ goat serum and incubated for overnight at $4{ }^{\circ} \mathrm{C}$ with rabbit anti-Cx43 (diluted 1:100, Novex, San Diego, CA, USA). The cells were then incubated for $1 \mathrm{~h}$ with FITC-conjugated goat anti-mouse IgG. Nuclei were stained with DAPI. Immunofluorescence images were captured using a confocal microscope (Zeiss LSM 700, Germany).

\section{Statistical analysis}

All biochemical data were analyzed with Student's t-test or a one-way analysis of variance (one-way ANOVA). Specific comparisons between any experimental group and a common control group were made using Dunnett's $t$-test. Comparisons between two experimental groups were made using the Student-Newman-Keuls method. Statistical significance was evaluated at the levels of $p<0.05$, $p<0.005$, and $p<0.001$.

\section{Results}

$1,25 D_{3}$ attenuated testosterone-induced aromatase expression and increased $17 \beta$-estradiol secretion

To examine whether $1,25 \mathrm{D}_{3}$ and testosterone regulate aromatase expression and $17 \beta$-estradiol secretion in granulosa cells, we treated cells with 0.1 or $1 \mu \mathrm{g} / \mathrm{mL}$ testosterone or $0.1 \mu \mathrm{M} 1,25 \mathrm{D}_{3}$ plus $1 \mu \mathrm{g} / \mathrm{mL}$ testosterone for $24 \mathrm{~h}$. Western blot analysis revealed that both doses of testosterone increased the aromatase levels $(p<$ 0.005 ; Figure 1A) compared to vehicle-treated cells, and addition of $0.1 \mu \mathrm{M} 1,25 \mathrm{D}_{3}$ resulted in a significant decrease of the $1 \mu \mathrm{g} / \mathrm{mL}$ testosterone-induced aromatase levels $(p<0.005 ;$ Figure 1A). Additionally, treatment with $1,25 \mathrm{D}_{3}$ alone attenuated aromatase expression compared to vehicle treatment ( $p<0.05$; Figure $1 \mathrm{~A})$. We also examined $17 \beta$-estradiol secretion using a radioimmunoassay and found that both testosterone-treated 
A
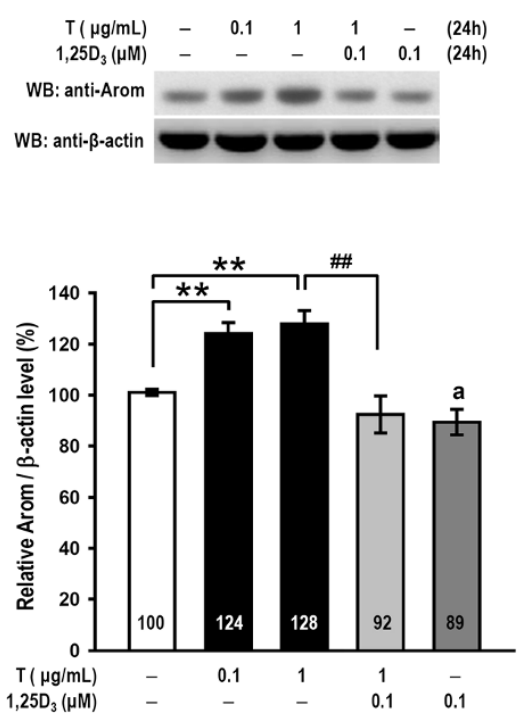

B
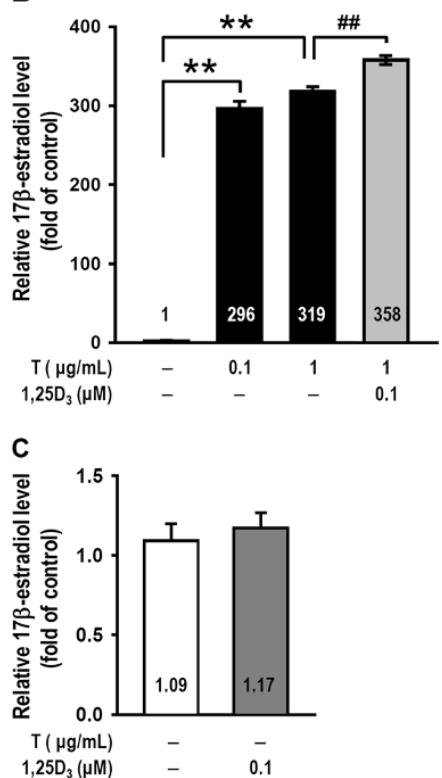

Figure 1 1,25D 3 attenuated testosterone-induced aromatase expression but improved $17 \beta$-estradiol secretions. Ovarian granulosa cells from rats were pretreated with $1,25 \mathrm{D}_{3}(0.1 \mu \mathrm{M})$ for $15 \mathrm{~min}$ and subsequently treated with $0.1 \mu \mathrm{g} / \mathrm{mL}$ or $1 \mu \mathrm{g} / \mathrm{mL}$ testosterone $($ denoted by $\mathrm{T}$ ) or vehicle (denoted by -) for 24 h. (A) Cells were lysed for protein extraction, and cell lysates were subjected to western blot analysis for aromatase protein detection. The level of aromatase (denoted by Arom) expression was estimated by densitometric analyses after normalization with the $\beta$-actin signal ( $n=5-6$ in each group). (B and $\mathbf{C}$ ) 17 -Estradiol secretions from the granulosa cells were collected from the medium and assessed over the course of a 24-h period of drug treatments. $17 \beta$-Estradiol release data were expressed as the fold-change relative to the vehicle-treated control ( $n=4-5$ in each group). The values represent the means \pm SEM. ${ }^{* *}, p<0.005$ for comparison with the vehicle-treated group; \#\#, $p<0.005$ for comparison of testosterone $/ 1,25 \mathrm{D}_{3}$ and testosterone alone; $\mathrm{a}, p<0.05$ for comparison of $1,25 \mathrm{D}_{3}$ alone and vehicle-treated group. The values listed within column indicate the means.

groups clearly experienced enhanced $17 \beta$-estradiol secretion $(p<0.005$; Figure $1 \mathrm{~B})$. The $1,25 \mathrm{D}_{3} /$ testosterone group exhibited significantly increased $17 \beta$-estradiol secretion relative to the group without $1,25 \mathrm{D}_{3}$ treatment $(p<$ $0.005)$. Treatment of cells with $0.1 \mu \mathrm{M} 1,25 \mathrm{D}_{3}$ alone for $24 \mathrm{~h}$ did not result in a significant increase in $17 \beta$-estradiol secretion $(p>0.05$; Figure $1 C)$. These results indicate that $1,25 \mathrm{D}_{3}$ has the potential to improve testosteroneinduced $17 \beta$-estradiol secretion but causes a decrease in testosterone-induced aromatase expression.

\section{$1,25 \mathrm{D}_{3}$ significantly increased aromatase tyrosine phosphorylation}

We evaluated whether the phosphorylation of aromatase was regulated by testosterone and $1,25 \mathrm{D}_{3}$ using immunoprecipitation-western blot analysis. We determined that the $1,25 \mathrm{D}_{3}$ /testosterone group exhibited significantly increased the level of aromatase tyrosine phosphorylation at $24 \mathrm{~h}$ relative to the testosterone group ( $p<0.05$; Figure $2 \mathrm{~A}$, left), and $1,25 \mathrm{D}_{3}$ alone also significantly increased the level of aromatase tyrosine phosphorylation relative to the control group $(p<0.05$; Figure 2A, right). The left panel in Figure $2 \mathrm{~B}$ is a positive control that was both immunoprecipitated and immunoblotted with an anti-aromatase antibody, and the right panel is a negative control for IgG. The lysate of the granulosa cells treated with $1,25 \mathrm{D}_{3} /$ testosterone showed a significant band attributed to immunoprecipitated aromatase phosphotyrosine and a weak band for IgG.

We next investigated the time course of the phosphotyrosine response to testosterone and to $1,25 \mathrm{D}_{3} /$ testosterone. Our data demonstrate that testosterone treatment induced aromatase tyrosine phosphorylation at $10 \mathrm{~min}, 30 \mathrm{~min}$ and $1 \mathrm{~h}$, whereas $1,25 \mathrm{D}_{3}$ improved the effect of testosterone at $30 \mathrm{~min}$ and increased the duration of the effect to $6 \mathrm{~h}(p<0.05$; Figure $2 \mathrm{C})$ and $24 \mathrm{~h}$ (Figure 2A). We also collected the medium for the $17 \beta$ estradiol assay and determined that testosterone-induced $17 \beta$-estradiol secretion increased at $30 \mathrm{~min}, 1 \mathrm{~h}(p<$ $0.05)$ and $6 \mathrm{~h}(\mathrm{n}=5 ; p<0.001$; Figure $2 \mathrm{D})$. There was no difference in $17 \beta$-estradiol secretion between the testosterone-treated groups and the $1,25 \mathrm{D}_{3} /$ testosteronetreated groups at up to $6 \mathrm{~h}(p>0.05$; Figure 2D). We also collected the medium 18-24 h after drug treatment and found that the $1,25 \mathrm{D}_{3} /$ testosterone-treated group significantly increased $17 \beta$-estradiol secretion $(p<0.05$; Figure $2 \mathrm{E}$ ). These studies demonstrated that $1,25 \mathrm{D}_{3}$ increased aromatase tyrosine phosphorylation and $17 \beta$ estradiol secretion. 


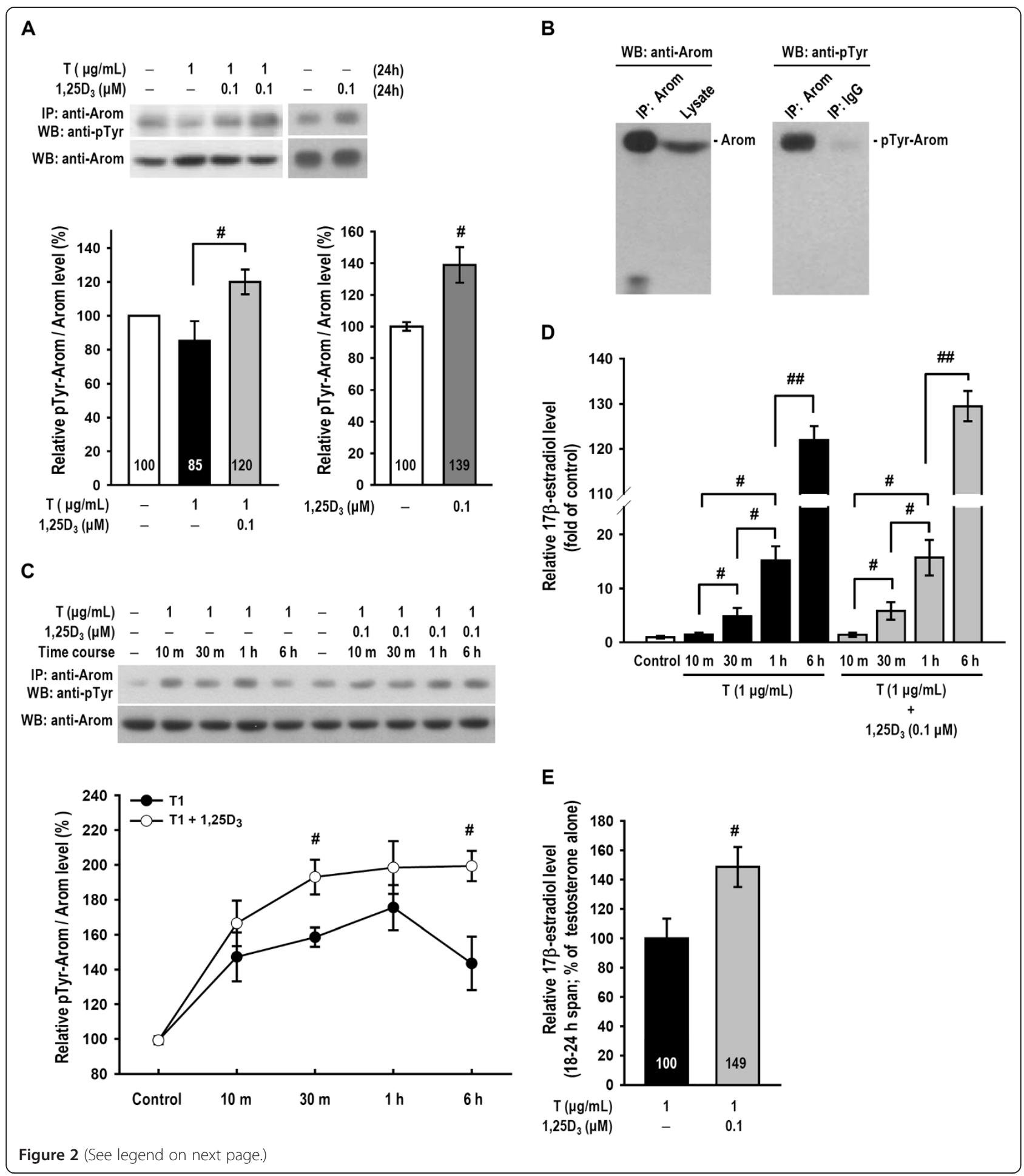


(See figure on previous page.)

Figure 2 1,25D $\mathrm{D}_{3}$ enhanced testosterone-induced aromatase tyrosine phosphorylation and 17ß-estradiol secretion during 18-24 h. (A) Rat ovarian granulosa cells were treated with vehicle, testosterone, testosterone plus $1,25 \mathrm{D}_{3}$ or $1,25 \mathrm{D}_{3}$ alone for $24 \mathrm{~h}$ ( $\mathrm{h}=4-5 \mathrm{in}$ each group). Aromatase was immunoprecipitated before being subjected to SDS-PAGE for resolution. The resultant blot was probed using both phosphotyrosine and aromatase antibodies. The expression of aromatase tyrosine phosphorylation (denoted by pTyr-Arom) was normalized to the corresponding aromatase expression and is represented as a percentage relative to the vehicle-treated control. (B) The left panel is a positive control that was both immunoprecipitated and immunoblotted with an anti-aromatase antibody. The lysate was also immunoprecipitated with the anti-aromatase antibody or lgG and immunoblotted with an anti-phosphotyrosine antibody, as shown in the right panel. A weak band in the lgG lane is as a negative control. (C) Cells were treated with testosterone alone or testosterone plus $1,25 D_{3}$ as indicated for various time periods ( $n=4-5$ in each group). Each pTyr-Arom level was normalized using the corresponding aromatase level and is represented as a percentage relative to the vehicle-treated control. (D) After treatment for various time periods as indicated, the 17ß-estradiol production levels were measured by radioimmunoassay. (E) After treatment with testosterone alone or testosterone plus $1,25 \mathrm{D}_{3}$ for $18 \mathrm{~h}$, the culture medium was removed and then replaced with fresh medium. Cells were continuously treated for another $6 \mathrm{~h}(18-24 \mathrm{~h}$ span). After the final $6 \mathrm{~h}$, medium was collected and the 17ß-estradiol secretion levels were measured by radioimmunoassay ( $\mathrm{n}=6 \mathrm{in}$ each group). The values represent the means \pm SEM. \#, $p<0.05 ; \#, p<0.005$ for comparison of the two treatment groups. The values listed within column indicate the means.

\section{$1,25 D_{3}$ and testosterone-induced $17 \beta$-estradiol production was mediated by calcium}

One possible mechanism for $1,25 \mathrm{D}_{3}$ /testosterone modulation of $17 \beta$-estradiol production is through increasing calcium concentrations. We studied whether NIF or BAPTA-AM could inhibit $1,25 \mathrm{D}_{3} /$ testosterone-regulated $17 \beta$-estradiol secretion. A radioimmunoassay of $17 \beta$ - estradiol production is presented in Figure 3. Statistical analysis revealed that testosterone doses $(0.01,0.1$ and $1 \mu \mathrm{g} / \mathrm{mL})$ increased $17 \beta$-estradiol production $(p<0.001$ and $p<0.005)$, and $1,25 \mathrm{D}_{3}(0.1 \mu \mathrm{M})$ increased high-dose $(1 \mu \mathrm{g} / \mathrm{mL})$ testosterone-induced $17 \beta$-estradiol secretion $(p<0.05$; Figure $3 \mathrm{~A})$. Our data demonstrate that pretreatment with NIF reduced $1,25 \mathrm{D}_{3}$ and testosterone
A

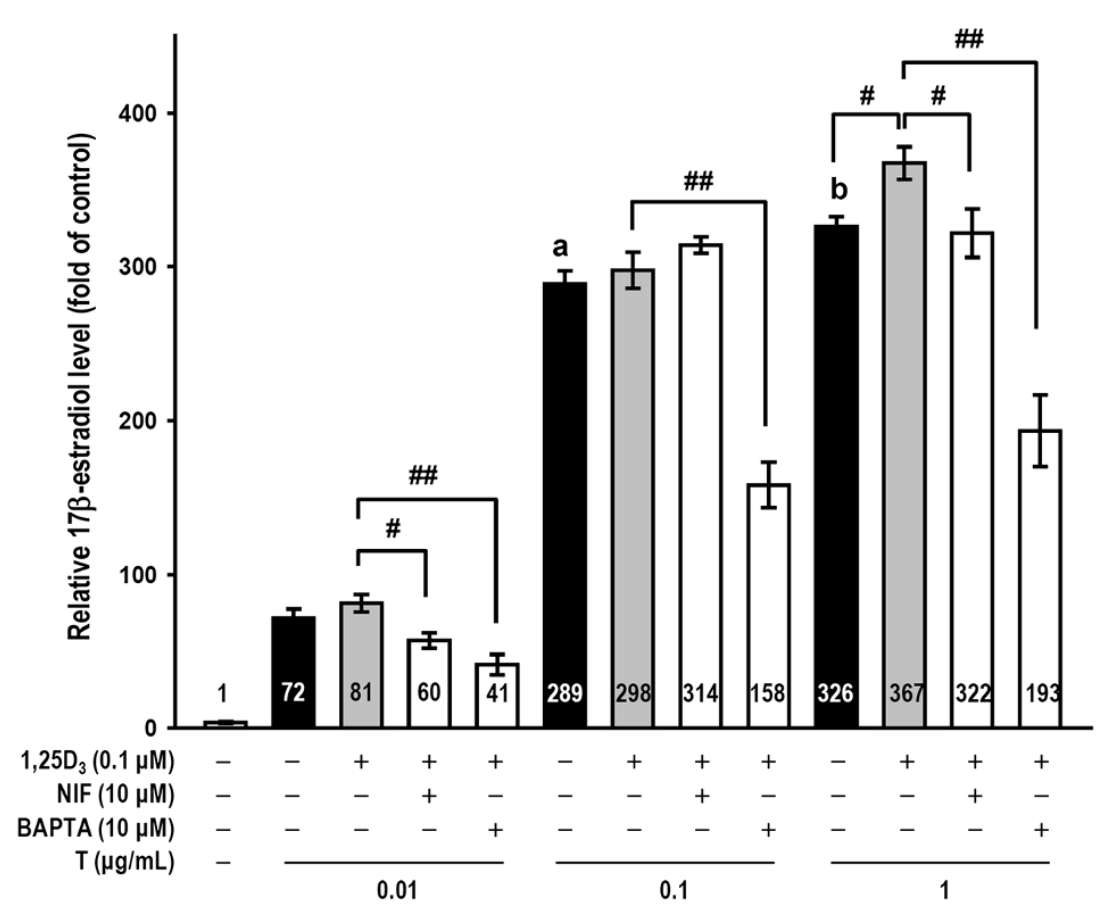

B

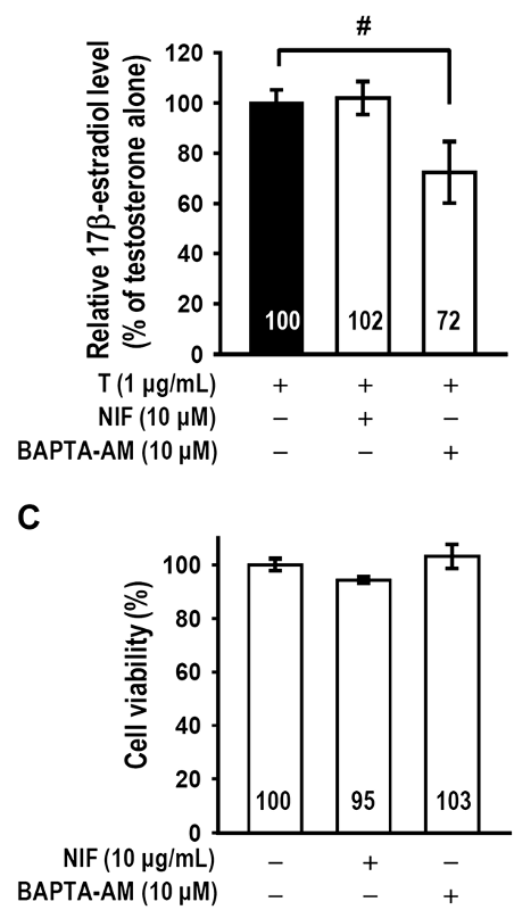

Figure $31,25 D_{3}$ and testosterone-induced $17 \beta$-estradiol secretion was mediated by calcium accumulation. (A) Granulosa cells were divided into vehicle, testosterone, testosterone plus 1,25 $\mathrm{D}_{3}$, L-type calcium channel blocker NIF $(10 \mu \mathrm{M})$ or intracellular calcium chelator BAPTAAM $(10 \mu M)$ pre-treatment groups ( $n=4-5$ in each group). The individual levels of $17 \beta$-estradiol were also assayed using a radioimmunoassay. (B) Testosterone-induced $17 \beta$-estradiol released by granulosa cells cultured with or without NIF or BAPTA-AM in the absence of $1,25 D_{3}$ was measured ( $n=9$ in each group). (C) After NIF or BAPTA-AM treatment for $24 \mathrm{~h}$, cells were subjected to the MTT reduction assay to measure cell viability. MTT reduction data are expressed as the percentage of values relative to the control group. The measurements were performed in triplicate, and each cytotoxicity experiment was repeated four times. The values represent the means $\pm \mathrm{SEM}$. \#, $p<0.05$; \#\#, $p<0.005$ for comparison of two drug groups; $a, p<0.001$ for comparison of $0.1 \mu \mathrm{g} / \mathrm{mL}$ and $0.01 \mu \mathrm{g} / \mathrm{mL}$ testosterone; $\mathrm{b}, p<0.05$ for comparison of $1 \mu \mathrm{g} / \mathrm{mL}$ and $0.1 \mu \mathrm{g} / \mathrm{mL}$ testosterone. The values listed within column indicate the means. 
(0.01 and $1 \mu \mathrm{g} / \mathrm{mL}$ )-enhanced $17 \beta$-estradiol secretion in granulosa cells $(p<0.05$; Figure $3 \mathrm{~A})$ but not testosterone $(1 \mu \mathrm{g} / \mathrm{mL})$-induced $17 \beta$-estradiol secretion (Figure $3 \mathrm{~B})$. BAPTA-AM reduced $17 \beta$-estradiol secretion induced by $1,25 \mathrm{D}_{3} /$ testosterone $(0.01,0.1$ and $1 \mu \mathrm{g} / \mathrm{mL})(p<0.001$; Figure $3 \mathrm{~A})$ and by testosterone $(1 \mu \mathrm{g} / \mathrm{mL})$ alone $(p<$ 0.05 ; Figure $3 \mathrm{~B})$. We also monitored cell viability using an MTT reduction assay. The viability of cultured cells exposed to NIF $(10 \mu \mathrm{M})$ or BAPTA-AM $(10 \mu \mathrm{M})$ did not significant differ from the control group $(p>0.05$; Figure $3 \mathrm{C}$ ). Thus, these data revealed that chelation of intercellular calcium with BAPTA-AM resulted in suppression of both testosterone- and $1,25 \mathrm{D}_{3}$ /testosteronemodulated $17 \beta$-estradiol secretion, while calcium from the L-type calcium channel was involved in only $1,25 \mathrm{D}_{3} /$ testosterone-modulated $17 \beta$-estradiol secretion in cultured granulosa cells.

\section{The effects of testosterone and $1,25 D_{3}$ on ER $\beta$ or VDR expression}

We examined the expression levels of ER $\beta$ and VDR in granulosa cells to determine if they were altered by testosterone and $1,25 \mathrm{D}_{3}$. Western blot analysis revealed that granulosa cells treated with testosterone $(0.1$ and $1 \mu \mathrm{g} / \mathrm{mL}$ ) exhibited markedly increased ER $\beta$ expression levels $(p<0.005$; Figure $4 \mathrm{~A})$ and that $1 \mu \mathrm{g} / \mathrm{mL}$ testosterone treatment increased ER $\beta$ expression more than treatment with $0.1 \mu \mathrm{g} / \mathrm{mL}$ testosterone $(p<0.05)$. However, the two doses of testosterone did not alter VDR levels $(p>0.05$; Figure 4B). Additionally, pre-treatment with $1,25 \mathrm{D}_{3}$ did not alter testosterone-induced ER $\beta$ expression and did not influence VDR expression $(\mathrm{n}=$ $3-4, p>0.05$; Figure 4A, B). Thus, testosterone alone affected ER $\beta$ expression, but $1,25 \mathrm{D}_{3}$ pre-treatment had no influence on ER $\beta$ or VDR in cultured granulosa cells.

\section{$1,25 D_{3}$ reversed testosterone-induced down-regulation of Cx43 in granulosa cells}

Finally, to examine whether $1,25 \mathrm{D}_{3}$ can affect the testosterone-induced down-regulation of $\mathrm{Cx} 43$, granulosa cells were treated with testosterone in the presence or absence of $0.1 \mu \mathrm{M} 1,25 \mathrm{D}_{3}$. We determined the cellular localization of $\mathrm{Cx} 43$ using immunofluorescence and observed its expression as green fluorescent plaques (Figure 5A). Cx43 protein expression was markedly decreased when cells were treated with a high dose of testosterone $(1 \mu \mathrm{g} / \mathrm{mL} ; p<0.005)$, but this effect was reversed by pre-treatment with $1,25 \mathrm{D}_{3} \quad(p<0.05$; Figure 5A, B). We performed a real-time PCR analysis and found that cultured cells pre-treated with $1,25 \mathrm{D}_{3}$ also reversed testosterone $(1 \mu \mathrm{g} / \mathrm{mL})$-induced downregulation of $\mathrm{Cx} 43(p<0.05$; Figure $5 \mathrm{C})$. These results indicated that $1,25 \mathrm{D}_{3}$ abolishes the inhibitory effect of testosterone on $\mathrm{Cx} 43$ expression in granulosa cells.

\section{Discussion}

Testosterone can induce concentration-dependent physiological and pathological effects. Physiologic levels of testosterone are converted into sufficient $17 \beta$-estradiol to improve follicular development, and the pathological
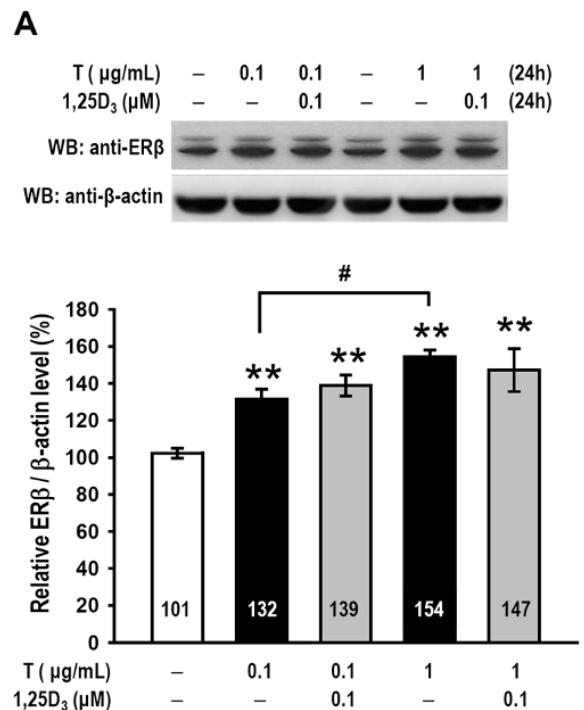

B
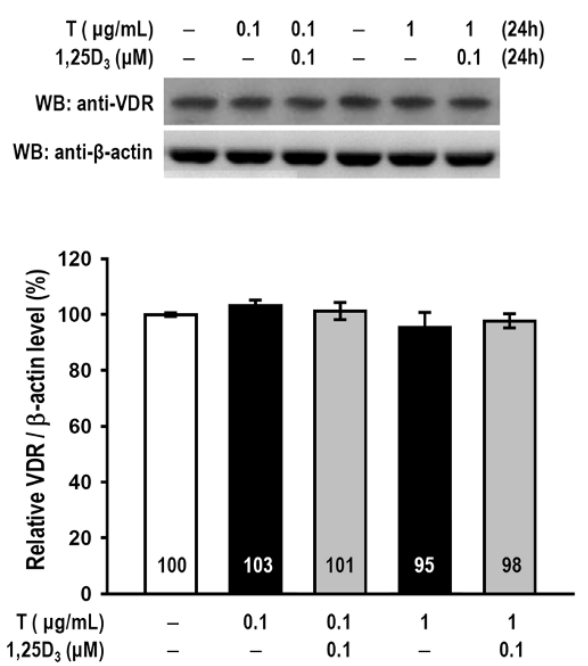

Figure 4 Testosterone, but not $1,25 D_{3}$, enhanced ER $\beta$ expression; testosterone and 1,25D 3 had no effect on VDR expression. Granulosa cells were pretreated with $1,25 D_{3}$ for 15 min and subsequently treated with one of two testosterone doses or vehicle for $24 \mathrm{~h}$ ( $\mathrm{n}=4-5$ in each group). The granulosa cell lysates were subjected to western blot analysis for (A) ER $\beta$ and (B) VDR expression levels. The levels of ER $\beta$ and VDR expression were quantified using densitometry and normalized to $\beta$-actin. The values represent the means \pm SEM. ${ }^{* *}, p<0.005$ for comparison with the vehicle-treated group. \#, $p<0.05$ for comparison of two drug groups. The values listed within column indicate the means. 


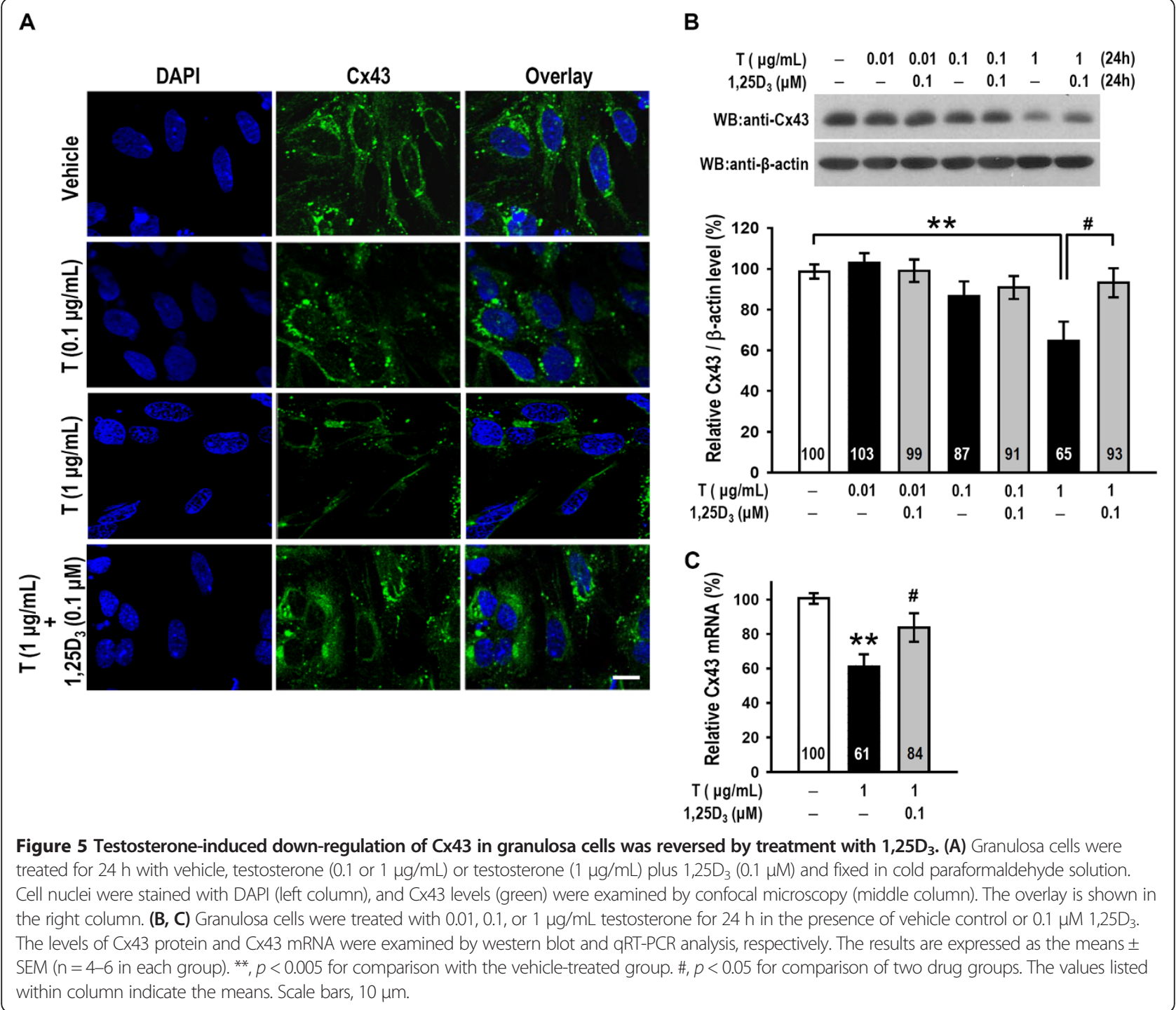

effects of testosterone may be due to induced hyperandrogenism and arrested follicular development. Androgen concentrations in the follicular fluid (FF) are higher in small follicles than in large follicles, and the androgen concentration in PCOS FF is higher than in FF from healthy women $[30,31]$. In the present study, we have demonstrated the dose dependence of testosterone-induced aromatase expression (Figure 1A) and 17 $\beta$-estradiol secretion (Figures 1B and $3 \mathrm{~A}$ ). These results are consistent with a previous report demonstrating that testosterone increases aromatase mRNA levels [2]. Testosterone increases the levels of aromatase mRNA promoter 1.1- and 1.5-derived transcripts at $1 \mu \mathrm{M}$ but only increases the promoter 2-derived transcript at the highest $(100 \mu \mathrm{M})$ dose [9]. Interestingly, we found that $1,25 \mathrm{D}_{3}$ reduced testosterone-induced aromatase expression but stimulated $17 \beta$-estradiol secretion (Figure 1A, B). $1,25 \mathrm{D}_{3}$ appears to modulate aromatase expression in the estrogenesis of granulosa cells and has been shown to exert tissue-specific effects on aromatase expression by various promoters [32]. For example, $1,25 \mathrm{D}_{3}$ increases aromatase expression in placental cells and osteoblasts but down-regulates aromatase expression in breast cancer cells [33-35]. Lundqvist et al. also demonstrated that a $1,25 \mathrm{D}_{3}$ analogue reduces aromatase expression by promoting dissociation of the co-modulator Williams syndrome transcription factor from the cyp19a1 promoter in breast cancer cells [36]. In addition, competition for shared coregulators between VDR and AR is one possible explanation for the suppressive effect of $1,25 \mathrm{D}_{3} / \mathrm{VDR}$ signals on AR transcriptional activity [37]. In our study, we found that treatment with $1,25 \mathrm{D}_{3}$ alone reduced aromatase expression but did not alter 17 $\beta$-estradiol secretion (Figure 1A, C). Thus, $1,25 \mathrm{D}_{3}$ exhibits a synergist effect in attenuating testosterone-induced aromatase expression.

Recently, aromatase activity was shown to mediate posttranslational modifications. Changes in aromatase activity 
often reflect differential protein expression arising from a slow rate of mRNA transcription. The phosphorylation of aromatase rapidly regulates estradiol production. For example, studies of murine aromatase suggest that serine 118 [38] or tyrosine 361 [20] can be phosphorylated and affect aromatase stability or activity. Specifically, increases in aromatase activity and estradiol secretion are regulated by c-Src kinase-catalysed tyrosine phosphorylation [20] and inhibits in aromatase activity by protein tyrosine phosphatase 1B in breast cancer cells [39]. In our study, although $1,25 \mathrm{D}_{3}$ inhibited aromatase protein expression, we also found that it can regulate tyrosine phosphorylation and change the activity of aromatase to improve $17 \beta$-estradiol secretion at longer times. We demonstrated that $1,25 \mathrm{D}_{3}$ treatment led to a significantly increased aromatase tyrosine phosphorylation level at $30 \mathrm{~min}, 6 \mathrm{~h}$ (Figure $2 \mathrm{C}$ ) and $24 \mathrm{~h}$ (Figure 2A, left) compared with testosterone alone (Figure 2A, C). 1,25 $\mathrm{D}_{3}$ also increased the level of aromatase tyrosine phosphorylation without testosterone at $24 \mathrm{~h}$ (Figure 2A, right). No difference in $17 \beta$-estradiol concentration between the testosterone and $1,25 \mathrm{D}_{3} /$ testosterone groups was observed within the first $6 \mathrm{~h}$ (Figure 2D), but $1,25 \mathrm{D}_{3}$ markedly increased $17 \beta-$ estradiol secretion at 18-24 h (Figure 2E). These results might suggest that a sustained, $1,25 \mathrm{D}_{3}$-induced increase in aromatase tyrosine phosphorylation maintains the effect of testosterone on $17 \beta$-estradiol secretion at $18-24 \mathrm{~h}$. Thus, the $13 \%$ increase in $17 \beta$-estradiol production might arise at later times during the $24 \mathrm{~h}$ treatment with $1,25 \mathrm{D}_{3}$. Because VDRs are located in the largest follicles, the $13 \%$ increase in $17 \beta$-estradiol from $1,25 \mathrm{D}_{3} /$ testosterone treatment might assist growth of the largest follicles. $1,25 \mathrm{D}_{3}$ might in this way inhibit aromatase expression and prevent aromatase excess syndrome, and increased aromatase tyrosine phosphorylation may rapidly regulate $17 \beta$ estradiol in the appropriate time frame.

$1,25 \mathrm{D}_{3}$ is also known to promote calcium absorption from intestinal cells [40]; however, there was no clear evidence suggesting that $1,25 \mathrm{D}_{3}$ increased calcium accumulation in granulose cells. Two different calcium channels (T-type and L-type) are involved in steroidogenesis in granulose cells [41]. In this study, we observed that an L-type calcium channel blocker reduced $17 \beta$-estradiol secretion under $1,25 \mathrm{D}_{3} /$ testosterone $(0.01 \mathrm{or} 1 \mu \mathrm{g} / \mathrm{mL})$ treatment (Figure $\left.3 \mathrm{~A}\right)$. $1,25 \mathrm{D}_{3} /$ testosterone-induced $17 \beta$-estradiol secretion was also significantly reduced by an intracellular calcium chelator. Additionally, NIF $(10 \mu \mathrm{M})$ or BAPTA-AM $(10 \mu \mathrm{M})$ alone did not cause cell toxicity (Figure $3 \mathrm{C}$ ), and this dose of BAPTA-AM also reduces testosterone-induced $17 \beta$ estradiol secretion without $1,25 \mathrm{D}_{3}$ (Figure $3 \mathrm{~B}$ ). These results are similar to a report that implicated a calcium-dependent pathway in mediation of gonadotropin-induced steroidogenesis in the ovary [42]. Weitzel et al. demonstrated that calcium signals are critical in the inhibition of low-density lipoprotein receptor-1-mediated estradiol production in murine granulosa cells [43]. Our data is the first to illustrate that stimulation of $17 \beta$-estradiol production by $1,25 \mathrm{D}_{3}$ and testosterone is mediated by the L-type calcium channel and intracellular calcium levels (Figure 3).

Several effects of $17 \beta$-estradiol have been shown to be important for follicular development and ovarian function, including the regulation of ER levels, stimulation of DNA synthesis, cell proliferation and regulation of atresia in ovarian follicles [44]. ER $\beta$ is the important ER member expressed in growing granulosa cells and the mature follicle in rodent ovaries and is critical to granulosa cell proliferation and differentiation [45]. We have demonstrated that testosterone-treated granulosa cells exhibited significantly increased ER $\beta$ levels and that $1,25 \mathrm{D}_{3}$ did not alter testosterone-induced ER $\beta$ expression (Figure 4A). This result is similar to the finding that the expression levels of ER $\beta$ mRNA in the ovaries of VDR-null mutant and wild-type mice are the same [16]. Additionally, both testosterone and $1,25 \mathrm{D}_{3}$ had no effect on VDR expression (Figure 4B). These results might suggest that testosterone or $1,25 \mathrm{D}_{3} /$ testosterone increases ER $\beta$ levels but not VDR levels.

Intercellular and intracellular endocrine regulatory mechanisms may be critical for follicle growth, dominant follicle selection, and follicle atresia. As ovarian follicles grow from the small to the large antral stage, granulosa cells provide $17 \beta$-estradiol by aromatase activation for dominant follicle development [46]. In contrast, other small follicles undergo atresia via apoptosis [47]. AR is expressed in primordial follicles, advancedstage follicles and primary follicles [5], and testosterone stimulates the early stages of follicle growth, inhibits preovulatory follicle apoptosis and limits follicle size [6]. Thus, the observation that many small follicles grow in PCOS may be explained by excess testosterone. Alternatively, $1,25 \mathrm{D}_{3}$ might inhibit the testosterone-stimulated early stages of follicular growth because $1,25 \mathrm{D}_{3}$ is known to inhibit the proliferation and induce the differentiation of a variety of cells [48], and VDR is expressed in the granulosa cells of largest follicle [49]. It is possible that $1,25 \mathrm{D}_{3}$ paired with testosterone preferentially improves the growth of larger follicles. Hence, the effect of $1,25 \mathrm{D}_{3}$ and testosterone on aromatase in granulosa cells might indicate a plausible treatment option for PCOS. Several reports have also shown that $1,25 \mathrm{D}_{3}$ regulates antimüllerian hormone (AMH) signalling, folliclestimulating hormone sensitivity, and progesterone production in human granulosa cells, and decreases the abnormally elevated AMH levels in $1,25 \mathrm{D}_{3}$-deficient women with PCOS, indicating a critical role for $1,25 \mathrm{D}_{3}$ in follicular development [50].

Intercellular communication via gap junctions is vitally important for granulosa cell differentiation and oocyte 
growth [22]. In this study, western blot analysis, qRT-PCR and immunostaining showed that high dose $(1 \mu \mathrm{g} / \mathrm{mL})$ of testosterone decreased $\mathrm{Cx} 43$ protein expression in granulosa cells, and this decrease was reversed by co-treatment with $0.1 \mu \mathrm{M} 1,25 \mathrm{D}_{3}$ (Figure 5). These results are similar to the finding that excess DHT down-regulates Cx43 in granulosa cells [25]. The correlation between abnormal androgen concentrations and $\mathrm{Cx} 43$ expression might contribute to the pathogenesis of PCOS, and $1,25 \mathrm{D}_{3}$ might prevent $\mathrm{Cx} 43$ down-regulation.

\section{Conclusions}

We determined that testosterone treatment increased aromatase expression and increased $17 \beta$-estradiol secretion in granulosa cells. $1,25 \mathrm{D}_{3}$ decreased testosteroneinduced aromatase expression but significantly increased aromatase phosphotyrosine levels and lengthened the duration of testosterone-induced $17 \beta$-estradiol secretion in rat granulosa cells to $18-24 \mathrm{~h}$. We also determined that $1,25 \mathrm{D}_{3} /$ testosterone-induced $17 \beta$-estradiol secretion is dependent on changes in calcium levels. Additionally, testosterone increased ER $\beta$ expression, but neither $1,25 \mathrm{D}_{3}$ nor testosterone mediated VDR expression. Finally, a high dose of testosterone reduced Cx43 expression, and $1,25 \mathrm{D}_{3}$ abolished testosterone-reduced $\mathrm{Cx} 43$ levels.

\section{Abbreviations}

AMH: Antimüllerian hormone; AR: Androgen receptors; BAPTA-AM: bis-(a-aminophe-noxy)-ethane-N,N,N',N'-tetraacetic acid tetra(acetoxymethyl)ester; Cx43: Connexin 43; 1,25D 1 : 1,25-dihydroxyvitamin $D_{3 i}$

DHT: Dihydrotestosterone; ER $\beta$ : Estradiol receptor $\beta$; FF: Follicular fluid; FSH: Follicle-stimulating hormone; NIF: Nifedipine; PCOS: Polycystic ovary syndrome; VDR: 1,25-dihydroxyvitamin $\mathrm{D}_{3}$ receptor.

\section{Competing interests}

The authors declare that they have no competing interests.

\section{Authors' contributions}

CTL conceived and performed experiments, conducted statistical analysis and drafted the manuscript. JYW and KYC contributed intellectual input toward the study's design and reviewed the manuscript. MIH supervised and contributed to data interpretation. All authors read and approved the final manuscript.

\section{Acknowledgments}

This work was supported by the Taiwan National Science Council Grant NSC 102-2629-B-038-001, Taipei Medical University of Taiwan (TMU98-AE1-B01) and Hsin Sheng College of Medical Care and Management of Taiwan (HSC-102-010). English language correction of this article has been accomplished by language editing services, ELSEVIER.

\footnotetext{
Author details

${ }^{1}$ Department of Nursing, Hsin Sheng College of Medical Care and Management, Taoyuan, Taiwan. ${ }^{2}$ Department of Neurology, School of Medicine, College of Medicine, Kaohsiung Medical University, Kaohsiung, Taiwan. ${ }^{3}$ General Education Center, National Taipei University of Nursing and Health Sciences, Taipei, Taiwan. ${ }^{4}$ Department of Obstetrics and Gynecology, Wan Fang Hospital, Taipei Medical University, Taipei, Taiwan.
}

Received: 8 May 2014 Accepted: 13 September 2014

Published: 20 September 2014

\section{References}

1. Ryan KJ: Biochemistry of aromatase: significance to female reproductive physiology. Cancer Res 1982, 42:3342s-3344s.

2. Luo W, Wiltbank MC: Distinct regulation by steroids of messenger RNAs for FSHR and CYP19A1 in bovine granulosa cells. Biol Reprod 2006, 75:217-225.

3. Belin F, Goudet G, Duchamp G, Gerard N: Intrafollicular concentrations of steroids and steroidogenic enzymes in relation to follicular development in the mare. Biol Reprod 2000, 62:1335-1343.

4. Stocco C: Aromatase expression in the ovary: hormonal and molecular regulation. Steroids 2008, 73:473-487.

5. Otala M, Makinen S, Tuuri T, Sjoberg J, Pentikainen V, Matikainen T, Dunkel L: Effects of testosterone, dihydrotestosterone, and 17beta-estradiol on human ovarian tissue survival in culture. Fertil Steril 2004, 82(Suppl 3):1077-1085.

6. Vendola KA, Zhou J, Adesanya OO, Weil SJ, Bondy CA: Androgens stimulate early stages of follicular growth in the primate ovary. J Clin Invest 1998, 101:2622-2629.

7. Murray AA, Gosden RG, Allison V, Spears N: Effect of androgens on the development of mouse follicles growing in vitro. J Reprod Fertil 1998, 113:27-33.

8. Hu YC, Wang PH, Yeh S, Wang RS, Xie C, Xu Q, Zhou X, Chao HT, Tsai MY, Chang $C$ : Subfertility and defective folliculogenesis in female mice lacking androgen receptor. Proc Natl Acad Sci U S A 2004, 101:11209-11214.

9. Hamel M, Vanselow J, Nicola ES, Price CA: Androstenedione increases cytochrome P450 aromatase messenger ribonucleic acid transcripts in nonluteinizing bovine granulosa cells. Mol Reprod Dev 2005, 70:175-183.

10. Wu YG, Bennett J, Talla D, Stocco C: Testosterone, not 5alphadihydrotestosterone, stimulates LRH-1 leading to FSH-independent expression of Cyp19 and P450scc in granulosa cells. Mol Endocrinol 2011, 25:656-668.

11. Hsu MI, Liou TH, Chou SY, Chang CY, Hsu CS: Diagnostic criteria for polycystic ovary syndrome in Taiwanese Chinese women: comparison between Rotterdam 2003 and NIH 1990. Fertil Steril 2007, 88:727-729.

12. Wehr E, Pilz S, Schweighofer N, Giuliani A, Kopera D, Pieber TR, ObermayerPietsch B: Association of hypovitaminosis D with metabolic disturbances in polycystic ovary syndrome. Eur J Endocrinol 2009, 161:575-582.

13. Wehr E, Trummer O, Giuliani A, Gruber HJ, Pieber TR, Obermayer-Pietsch B: Vitamin D-associated polymorphisms are related to insulin resistance and vitamin D deficiency in polycystic ovary syndrome. Eur J Endocrinol 2011, 164:741-749.

14. Lerchbaum E, Obermayer-Pietsch B: Vitamin D and fertility: a systematic review. Eur J Endocrinol 2012, 166:765-778.

15. Johnson JA, Grande JP, Roche PC, Kumar R: Immunohistochemical detection and distribution of the 1,25-dihydroxyvitamin D3 receptor in rat reproductive tissues. Histochem Cell Biol 1996, 105:7-15.

16. Kinuta K, Tanaka H, Moriwake T, Aya K, Kato S, Seino Y: Vitamin D is an important factor in estrogen biosynthesis of both female and male gonads. Endocrinology 2000, 141:1317-1324.

17. Boland R, Buitrago C, De Boland AR: Modulation of tyrosine phosphorylation signalling pathways by 1alpha,25(OH)2-vitamin D3. Trends Endocrinol Metab 2005, 16:280-287.

18. Buitrago C, Vazquez G, De Boland AR, Boland RL: Activation of Src kinase in skeletal muscle cells by 1,1,25-(OH(2))-vitamin $\mathrm{D}(3)$ correlates with tyrosine phosphorylation of the vitamin $\mathrm{D}$ receptor (VDR) and VDR-Src interaction. J Cell Biochem 2000, 79:274-281.

19. Buitrago C, Vazquez G, De Boland AR, Boland R: The vitamin D receptor mediates rapid changes in muscle protein tyrosine phosphorylation induced by 1,25(OH)(2)D(3). Biochem Biophys Res Commun 2001, 289:1150-1156.

20. Catalano S, Barone I, Giordano C, Rizza P, Qi H, Gu G, Malivindi R, Bonofiglio D, Ando S: Rapid estradiol/ERalpha signaling enhances aromatase enzymatic activity in breast cancer cells. Mol Endocrinol 2009, 23:1634-1645.

21. Cheng J, Watkins SC, Walker WH: Testosterone activates mitogen-activated protein kinase via Src kinase and the epidermal growth factor receptor in sertoli cells. Endocrinology 2007, 148:2066-2074.

22. Kidder GM, Mhawi AA: Gap junctions and ovarian folliculogenesis. Reproduction 2002, 123:613-620.

23. Teilmann SC: Differential expression and localisation of connexin-37 and connexin-43 in follicles of different stages in the 4-week-old mouse ovary. Mol Cell Endocrinol 2005, 234:27-35

24. Ackert CL, Gittens JE, O'Brien MJ, Eppig JJ, Kidder GM: Intercellular communication via connexin43 gap junctions is required for ovarian folliculogenesis in the mouse. Dev Biol 2001, 233:258-270. 
25. Wu CH, Yang JG, Yang JJ, Lin YM, Tsai HD, Lin CY, Kuo PL: Androgen excess down-regulates connexin43 in a human granulosa cell line. Fertil Steril 2010, 94:2938-2941

26. Clairmont A, Tessman D, Stock A, Nicolai S, Stahl W, Sies H: Induction of gap junctional intercellular communication by vitamin $D$ in human skin fibroblasts is dependent on the nuclear Induction of gap junctional intercellular communication by vitamin $D$ in human skin fibroblasts is dependent on the nuclear vitamin D receptor. Carcinogenesis 1996 17:1389-1391.

27. Ke FC, Fang SH, Lee MT, Sheu SY, Lai SY, Chen YJ, Huang FL, Wang PS, Stocco DM, Hwang JJ: Lindane, a gap junction blocker, suppresses FSH and transforming growth factor beta1-induced connexin43 gap junction formation and steroidogenesis in rat granulosa cells. J Endocrinol 2005 184:555-566.

28. Merhi Z, Doswell A, Krebs K, Cipolla M: Vitamin D alters genes involved in follicular development and steroidogenesis in human cumulus granulosa cells. J Clin Endocrinol Metab 2014, 99:E1137-1145.

29. Mosmann T: Rapid colorimetric assay for cellular growth and survival: application to proliferation and cytotoxicity assays. J Immunol Methods 1983, 65:55-63.

30. Teissier MP, Chable H, Paulhac S, Aubard Y: Comparison of follicle steroidogenesis from normal and polycystic ovaries in women undergoing IVF: relationship between steroid concentrations, follicle size, oocyte quality and fecundability. Hum Reprod 2000, 15:2471-2477.

31. Eilso Nielsen M, Rasmussen IA, Fukuda M, Westergaard LG, Yding Andersen C: Concentrations of anti-Mullerian hormone in fluid from small human antral follicles show a negative correlation with CYP19 mRNA expression in the corresponding granulosa cells. Mol Hum Reprod 2010, 16:637-643.

32. Lundqvist J, Norlin M, Wikvall K: 1alpha,25-Dihydroxyvitamin D3 exerts tissue-specific effects on estrogen and androgen metabolism. Biochim Biophys Acta 1811, 2011:263-270.

33. Krishnan AV, Swami S, Peng L, Wang J, Moreno J, Feldman D: Tissueselective regulation of aromatase expression by calcitriol: implications for breast cancer therapy. Endocrinology 2010, 151:32-42.

34. Enjuanes A, Garcia-Giralt N, Supervia A, Nogues X, Ruiz-Gaspa S, Bustamante M, Mellibovsky L, Grinberg D, Balcells S, Diez-Perez A: Functional analysis of the I.3, I.6, pll and I.4 promoters of CYP19 (aromatase) gene in human osteoblasts and their role in vitamin D and dexamethasone stimulation. Eur J Endocrinol 2005, 153:981-988.

35. Barrera D, Avila E, Hernandez G, Halhali A, Biruete B, Larrea F, Diaz L: Estradiol and progesterone synthesis in human placenta is stimulated by calcitriol. J Steroid Biochem Mol Biol 2007, 103:529-532.

36. Lundqvist J, Hansen SK, Lykkesfeldt AE: Vitamin D analog EB1089 inhibits aromatase expression by dissociation of comodulator WSTF from the CYP19A1 promoter-a new regulatory pathway for aromatase. Biochim Biophys Acta 1833, 2013:40-47.

37. Ting HJ, Bao BY, Hsu CL, Lee YF: Androgen-receptor coregulators mediate the suppressive effect of androgen signals on vitamin $D$ receptor activity. Endocrine 2005, 26:1-9.

38. Miller TW, Shin I, Kagawa N, Evans DB, Waterman MR, Arteaga CL: Aromatase is phosphorylated in situ at serine-118. J Steroid Biochem Mol Biol 2008, 112:95-101.

39. Barone I, Giordano C, Malivindi R, Lanzino M, Rizza P, Casaburi I, Bonofiglio D, Catalano S, Ando S: Estrogens and PTP1B function in a novel pathway to regulate aromatase enzymatic activity in breast cancer cells. Endocrinology 2012, 153:5157-5166.

40. Christakos S, Dhawan P, Porta A, Mady LJ, Seth T: Vitamin D and intestinal calcium absorption. Mol Cell Endocrinol 2011, 347:25-29.

41. Agoston A, Kunz L, Krieger A, Mayerhofer A: Two types of calcium channels in human ovarian endocrine cells: involvement in steroidogenesis. J Clin Endocrinol Metab 2004, 89:4503-4512.

42. Paul S, Kundu S, Pramanick K, Bandyopadhyay A, Mukherjee D: Regulation of ovarian steroidogenesis in vitro by gonadotropin in common carp Cyprinus carpio: interaction between calcium- and adenylate cyclasedependent pathways and involvement of ERK signaling cascade. $J \mathrm{Mol}$ Endocrinol 2010, 45:207-218.

43. Weitzel JM, Vernunft A, Kruger B, Plinski C, Viergutz T: LOX-1 regulates estrogenesis via intracellular calcium release from bovine granulosa cells. Cytometry A 2014, 85:88-93.

44. Reilly CM, Cannady WE, Mahesh VB, Stopper VS, De Sevilla LM, Mills TM: Duration of estrogen exposure prior to follicle-stimulating hormone stimulation is critical to granulosa cell growth and differentiation in rats. Biol Reprod 1996, 54:1336-1342.

45. Emmen JM, Couse JF, Elmore SA, Yates MM, Kissling GE, Korach KS: In vitro growth and ovulation of follicles from ovaries of estrogen receptor (ER) \{alpha\} and ER\{beta\} null mice indicate a role for ER\{beta\} in follicular maturation. Endocrinology 2005, 146:2817-2826.

46. Gougeon A: Human ovarian follicular development: from activation of resting follicles to preovulatory maturation. Ann Endocrinol (Paris) 2010, 71:132-143.

47. Matsuda F, Inoue N, Manabe N, Ohkura S: Follicular growth and atresia in mammalian ovaries: regulation by survival and death of granulosa cells. J Reprod Dev 2012, 58:44-50.

48. Kinuta K: Regulation of vitamin D biosynthesis by calcium. Clin Calcium 2003, 13:899-903.

49. Wojtusik J, Johnson PA: Vitamin D regulates anti-Mullerian hormone expression in granulosa cells of the hen. Biol Reprod 2012, 86:91.

50. Irani M, Merhi Z: Role of vitamin D in ovarian physiology and its implication in reproduction: a systematic review. Fertil Steril 2014, 102:460-468. e463.

doi:10.1186/1477-7827-12-90

Cite this article as: Lee et al:: 1,25-Dihydroxyvitamin D3 increases testosterone-induced $17 \mathrm{beta}$-estradiol secretion and reverses testosterone-reduced connexin 43 in rat granulosa cells. Reproductive Biology and Endocrinology 2014 12:90.

\section{Submit your next manuscript to BioMed Central and take full advantage of:}

- Convenient online submission

- Thorough peer review

- No space constraints or color figure charges

- Immediate publication on acceptance

- Inclusion in PubMed, CAS, Scopus and Google Scholar

- Research which is freely available for redistribution 